\title{
Pengaruh Literasi Keuangan dan Faktor Demografi Terhadap Keputusan Investasi Mahasiswa FE Universitas Sarjanawiyata Tamansiswa
}

\author{
Muhammad Ahkam Al-Aziz ${ }^{1 *}$, Risal Rinofah ${ }^{2}$ \\ Universitas Sarjanawiyata Tamansiswa \\ *Correspondence email: ahkamalaziz@gmail.com, risal.rinofah@ustjogja.ac.id
}

\begin{abstract}
Abstrak. Penelitian ini bertujuan untuk mengetahui pengaruh literasi keuangan dan faktor demografi seperti jenis kelamin, tahun angkatan dan pendapatan terhadap keputusan investasi mahasiswa di Fakultas Ekonomi Universitas Sarjanawiyata Tamansiswa. Responden pada penelitian ini berjumlah 100 mahasiswa yang berasal dari FE UST angkatan 2017 sampai 2020. Metode yang digunakan pada penelitian kali ini menggunakan metode kuantitatif. Sedangkan metode analisis data yang digunakan, antara lain analisis deskriptif, uji validitas dan reabilitas, serta uji regresi berganda dengan bantuan program SPSS 20. Hasil penelitian ini menunjukan bahwa literasi keuangan berpengaruh positif signifikan terhadap keputusan investasi. Namun, pada faktor demografi hanya tahun angkatan yang berpengaruh positif signifikan terhadap keputusan investasi. Sedangkan tahun angkatan dan pendapatan tidak berpengaruh positif signifikan terhadap keputusan investasi.
\end{abstract}

Kata Kunci : Literasi Keuangan, Faktor Demografi dan Keputusan Investasi

\begin{abstract}
This study aims to find out the influence of financial literacy and demographic factors such as gender, generation year and income on student investment decisions at the Faculty of Economics Sarjanawiyata Tamansiswa University. Respondents to this study numbered 100 students from FE UST class of 2017 to 2020. The method used in this research uses quantitative methods. While the data analysis method used, among others descriptive analysis, validity and reliability test, and multiple regression test with the help of SPSS 20 program. The results of this study show that financial literacy has a significant positive effect on investment decisions. However, on demographic factors only the year of the force has a significant positive effect on investment decisions. While the year of force and income has no significant positive effect on investment decisions.
\end{abstract}

Keywords: Financial Literacy, Demographic Factors and Investment Decisions

\section{Pendahuluan}

Di era globalisasi saat ini, masih banyak masyarakat yang belum menyadari akan pentingnya peran pengelolaan keuangan dalam kehidupan pribadinya (Pritazahara \& Sriwidodo, 2015). Mengelola uang yang sehat membutuhkan beberapa faktor fundamental yang perlu ditingkatkan, dan salah satunya adalah literasi keuangan (Rasyid, 2012). Literasi keuangan dapat membantu seseorang dalam melakukan perencanaan dan juga pengambilan keputusan keuangan yang baik dapat mencapai tujuan yang ingin dicapai yaitu kesejahteraan financial di masa yang akan datang (Faidah, 2019). Literasi keuangan didefinisikan sebagai kemampuan seorang individu untuk mengambil keputusan dan mengelola dana yang dimilikinya secara bijak (Aini, Syafitri, \& Wijaya, 2016). Individu dengan literasi keuangan yang baik, tidak hanya berdampak pada efektivitas alokasi keuangan, namun juga mampu membuat keputusan secara cermat dan terampil dalam pembelian produk-produk keuangan maupun jasa, seperti KPR rumah, investasi dana pensiun, asuransi, pembelian saham, obligas, dll (Kusumawarhani, Cahyawani, \& Ningrum, 2020).

Selain literasi keuangan, ada faktor lain yang mempengaruhi keputusan investasi yaitu faktor demografi dimana faktor demografi tersebut dapat mempengaruhi perilaku seseorang termasuk dalam mengelola keuangannya (Hidayati \& Kartawinata, 2017). Faktor demografi merupakan faktor yang melekat pada diri seseorang dan membedakan antara individu satu dengan individu lainnya. Faktor demografi termasuk pendapatan, usia, jenis kelamin, pengalaman pendidikan dan tingkat pendidikan (Aminatuzzahra, 2014). Penelitian yang dilakukan oleh (Aini et al., 2016) menghasilkan bahwa literasi keuangan mempengaruhi keputusan investasi di pasar modal secara signifikan. Begitu pula dengan penelitian yang dilakukan (Aminatuzzahra, 2014) juga menghasilkan bahwa pengetahuan keuangan, sikap keuangan dan sosial demografi berpengaruh signifikan terhadap keputusan investasi individu.

Sementara itu, pada penelitian (Chen \& Volpe, 1998) yang berjudul An Analysis of Personal Financial Literacy Among College Students. Pada penelitian ini menyimpulkan bahwa Tahun angkatan berpengaruh terhadap literasi keuangan mahasiswa. Mahasiswa yang telah lulus (alumni) memiliki pengetahuan keuangan pribadi yang lebih baik dibanding mahasiswa junior maupun senior. Penelitian lain dari (Kusumawarhani et al., 2020) menyimpulkan juga bahwa mahasiswa dengan tahun masuk lebih awal (senior) memiliki tingkat pengetahuan literasi keuangan yang lebih tinggi daripada mahasiswa dengan tahun masuk akhir (junior). Melihat dari penelitian-penelitian di atas, penelitian mengenai pengaruh literasi keuangan dan faktor demografi belum ada yang berfokus di Fakultas Ekonomi 
Universitas Sarjanawiyata Tamansiswa. Latar belakang itulah yang membuat penulis ingin membuktikan pengaruh literasi keuangan dan faktor demografi berpengaruh terhadap keputusan berinvestasi mahasiswa FE UST.

\section{Metode}

Penelitian ini merupaka penelitian jenis kasual dengan pendekatan kuantitatif. Data yang digunakan dalam penelitian ini adalah data primer yang diperoleh dari kuisioner yang diseberkan kepada responden. Pengukuran instrumen yang digunakan pada variabel literasi keuangan menggunakan skala Likert.

Dalam penelitian ini digunakan 5 jenjang skala, yaitu : 1 = Sangat Tidak Setuju (STS); 2 = Tidak Setuju (TS)' $3=$ Netral; 4 = Setuju (S); 5 = Sangat Setuju (SS)

Penelitian kali ini, populasinya yaitu Mahasiswa Fakultas Ekonomi Universitas Sarjanawiyata Tamansiswa. Jumlah popuasi dari Mahasiswa FE UST sendiri yaitu sebanyak 2731 mahasiswa. Sedangkan teknik yang digunakan dalam penentuan sampel ini mengguanakan teknik purposive sampling. Purposive sampling adalah teknik penentuan sampel dengan pertimbangan atau kriteria tertentu. Kriteria responden dalam penelitian ini, antara lain: 1. Mahasiswa aktif FE UST; 2. Mahasiswa angkatan 2017, 2018, 2019, dan 2020; dan 3. Mahasiswa yang sudah memiliki pendapatan pribadi.

Dikarenakan jumlah mahasiswa FE UST yang sudah memiliki pendapatan pribadi tidak diketahui jumlahnya dengan rinci, maka untuk menentukan sampel pada penelitian kali ini menggunakan Rumus Lameshow. Rumus Lameshow digunakan ketika peneliti akan mencari jumlah sampel dari populasi, namun jumlah populasi yang sesuai kriteria jumlah pastinya belum tahu.

Rumus Lameshow sebagai berikut :

$n=\frac{Z \propto^{2} \times P \times Q}{L^{2}}$

Dengan $: \mathrm{n}=$ jumlah sampel minimal yang diperlukan; $\mathrm{Z} \alpha=$ Nilai standar dari distribusi sesuai nilai; $\alpha=5 \%=1.96 ; \mathrm{P}$ $=$ Prevelasi outcome, karena data belum didapat, maka dipakai 50\%; Q =1-P; L = Tingkat ketelitian 10\%

Berdasarkan rumus, maka

$n=\frac{(1.96)^{2} \times 0.5 \times 0.5}{(0.1)^{2}}=96,04$

Maka diperoleh hasil jumlah sampel minimal yang dibutuhkan dalam penelitian ini adalah 96 responden. Pengambilan responden dibulatkan menjadi 100 responden. Metode pengumpulan data menggunakan kuisioner lewat Google Form yang diberikan kepada responden yang sesuai dengan kriteria. Kuisioner berisi pertanyaan-pertanyaan seputar literasi keuangan, faktor demografi dan keputusan investasi. Tempat pelaksanaan penelitian ini dilakukan secara online melalui Google Formulir (G-Form). Sedangkan waktu pelaksanaan penelitian ini berlangsung mulai Februari 2021 sampai selesai.

\section{Hasil}

Sampel dalam penelitian ini adalah Mahasiswa Fakultas Ekonomi Universitas Sarjanawiyata Tamansiswa dan data yang terkumpul sejumlah 100. Kuisioner dibagikan melalui Google Forms dimana kuisioner tersebut berisi data demografi mahasiswa, pertanyaan mengenai literasi keuangan dan keputusan investasi. Karakteristik responden dalam penelitian ini yaitu berkategorikan 48 orang (48\%) laki-laki dan 52 orang (52\%) perempuan. Sedangkan pada kategori tahun angkatan, jumlah responden yang angkatan tahun 2017 sebanyak 34 mahasiswa (34\%), kemudian mahasiswa angkatan 2018 sebanyak 20 (20\%), tahun angkatan 2019 sebanyak 25 mahasiswa (25\%) dan mahasiswa tahun angkatan 2020 sebanyak 21 (21\%). Selain itu, pada kategori jumlah pendapatan menghasilkan sebanyak 40 mahasiswa (40\%) mempunyai jumlah pendapatan Rp 500.000 - Rp 1.000.000, 21 mahasiswa (21\%) berpendapatan Rp 1.000.000 - Rp 1.500.000, 17 mahasiswa (17\%) berpendapatan Rp 1.500.000 - Rp 2.000 .000 dan 22 mahasiswa (22\%) mempunyai pendapatan $>$ Rp2.000.000 per-bulannya.

\section{Uji Validitas}

Literasi Keuangan 
Muhammad Ahkam Al-Aziz dan Risal Rinofah, Pengaruh Literasi Keuangan dan Faktor Demografi Terhadap Keputusan Investasi Mahasiswa FE Universitas Sarjanawiyata Tamansiswa

Tabel 1

Literasi Keuangan

\begin{tabular}{|c|c|c|c|}
\hline Item & r litung & $r_{\text {tabel }}$ & Keterangan \\
\hline Pertanyaan & & & \\
\hline Item 1 & 0,700 & 0,1966 & Valid \\
\hline Item 2 & 0,461 & 0,1966 & Valid \\
\hline Item 3 & 0,617 & 0,1966 & Valid \\
\hline Item 4 & 0,592 & 0,1966 & Valid \\
\hline Item 5 & 0,540 & 0,1966 & Valid \\
\hline Item 6 & 0,578 & 0,1966 & Valid \\
\hline Item 7 & 0,689 & 0,1966 & Valid \\
\hline Item 8 & 0,260 & 0,1966 & Valid \\
\hline Item 9 & 0,473 & 0,1966 & Valid \\
\hline Item 10 & 0,541 & 0,1966 & Valid \\
\hline Item 11 & 0,579 & 0,1966 & Valid \\
\hline Item 12 & 0,580 & 0,1966 & Valid \\
\hline Item 13 & 0,537 & 0,1966 & Valid \\
\hline Item 14 & 0,568 & 0,1966 & Valid \\
\hline Item 15 & 0,731 & 0,1966 & Valid \\
\hline Item 16 & 0,604 & 0,1966 & Valid \\
\hline Item 17 & 0,691 & 0,1966 & Valid \\
\hline Item 18 & 0,442 & 0,1966 & Valid \\
\hline Item 19 & 0,562 & 0,1966 & Valid \\
\hline Item
\end{tabular}

Sumber : Data primer yang diolah, 2021

Didasarkan pada perbandingan $r_{\text {hitung }}$ dan $r_{\text {tabel. }}$ Dari data di atas, dapat diketahui bahwa setiap item pertanyaan dinyatakan valid karena $r_{\text {hitung }}>r_{\text {tabel. }} R_{\text {tabel }}=0,1966(\mathrm{df}=\mathrm{N}-2 ; 100-2=98$ pada $\alpha=0,05)$ dimana nilai dari $r_{\text {tabel }}$ sebesar 0,1966 sehingga 19 pertanyaan tersebut memenuhi syarat (valid).

Tabel 2

Keputusan Investasi

\begin{tabular}{|c|c|c|c|}
\hline Item & ritung & rtabel & Keterangan \\
Pertanyaan & & & \\
\hline Item 1 & 0,804 & 0,1966 & Valid \\
\hline Item 2 & 0,742 & 0,1966 & Valid \\
\hline Item 3 & 0,761 & 0,1966 & Valid \\
\hline Item 4 & 0,696 & 0,1966 & Valid \\
\hline Item 5 & 0,715 & 0,1966 & Valid \\
\hline Item 6 & 0,769 & 0,1966 & Valid \\
\hline
\end{tabular}

Sumber : Data primer yang diolah, 2021

Data di atas dapa diketahui bahwa setiap item pertanayaan dinyatakan valid karena $r_{\text {hitung }}>r_{\text {tabel. }} R_{\text {tabel }}=0,1966$ $(\mathrm{df}=\mathrm{N}-2 ; 100-2=98$ pada $\alpha=0,05)$ dimana nilai dari setiap $\mathrm{r}_{\text {tabel }}$ sebesar 0,1966 sehingga 6 pertanyaan tersebut memenuhi syarat.

\section{Uji Reliabilitas}

Tabel 3

Hasil uji reliablitas

\begin{tabular}{|l|l|c|c|}
\hline NO. & Variabel & $\begin{array}{c}\text { Cronbach } \\
\text { alpha }\end{array}$ & Keterangan \\
\hline 1. & $\begin{array}{l}\text { Literasi } \\
\text { Keuangan }\end{array}$ & 0,911 & Reliabel \\
\hline 2. & $\begin{array}{l}\text { Keputusan } \\
\text { Investasi }\end{array}$ & 0,908 & Reliabel \\
\hline
\end{tabular}

Sumber : Data primer yang diolah, 2021 
Muhammad Ahkam Al-Aziz dan Risal Rinofah, Pengaruh Literasi Keuangan dan Faktor Demografi Terhadap Keputusan Investasi Mahasiswa FE Universitas Sarjanawiyata Tamansiswa

Suatu instrumen dikatakan reliabel apabila nilai cronbach alpha $>0,6$. Berdasarkan tabel diatas diketahui bahwa semua variabel dikatakan reliabel karena nilai dari cronbach alpha $>0,6$.

\section{Uji Normalitas}

\section{Grafik 1}

Normal PP Plot

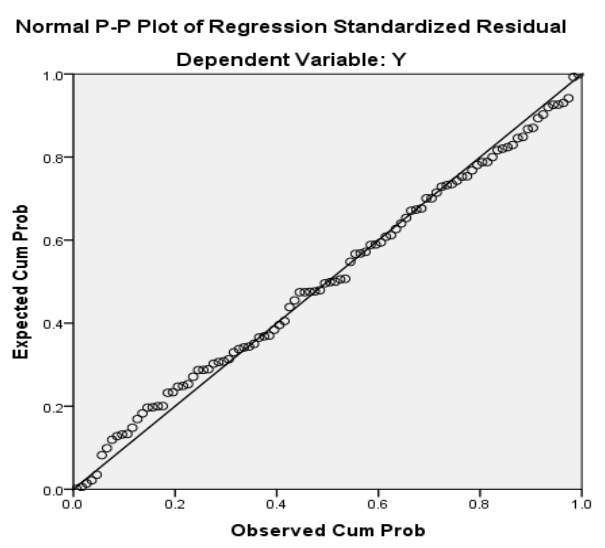

Berdasarkan gambar di atas, dapat dilihat bahwa data yang tersebar cenderung mengikuti garis normal sehingga dapat disimpulkan bahwa tidak adanya gejala normalitas.

\section{Uji Multikolinieritas}

Tabel 4

Hasil Uji Multikolinieritas

\begin{tabular}{|l|c|c|}
\hline \multirow{2}{*}{ Model } & \multicolumn{2}{|c|}{ Collinearity Stastics } \\
\cline { 2 - 3 } & Tolerance & VIF \\
\hline Literasi Keuangan & 0,554 & 1,806 \\
\hline Jenis Kelamin & 0,835 & 1,197 \\
\hline Tahun Angkatan & 0,788 & 1,270 \\
\hline Jumlah Pendapatan & 0,753 & 1,328 \\
\hline
\end{tabular}

Sumber: data olahan

Berdasarkan tabel di atas, dapat di lihat bahwa variabel independen yang meliputi literasi keuangan memiliki nilai 1,806, jenis kelamin sebesar 1,197, tahun angkatan sebesar 1,270 dan jumlah pendapatan sebesar 1,328. Hal itu berarti seluruh variabel memiliki nilai VIF $<10$, sehigga dapat disimpulkan bahwa tidak adanya gejala multikolenieritas pada penelitian ini.

\section{Uji Heteroskedastisitas}

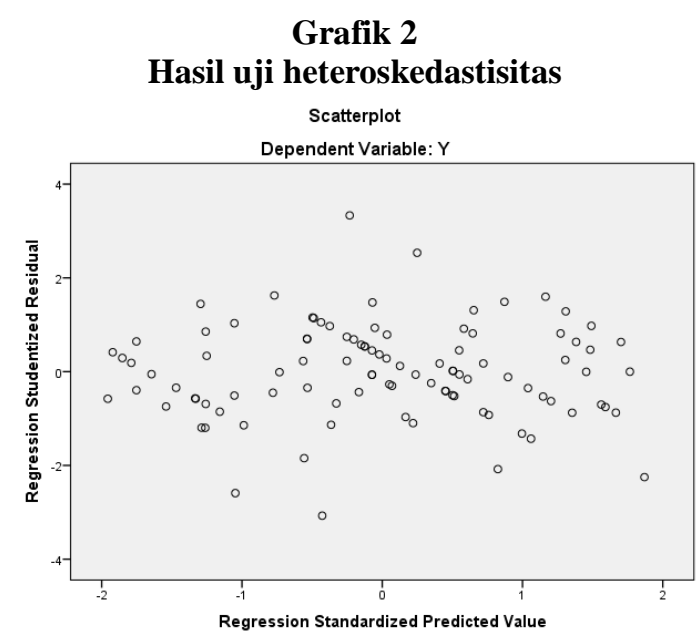


Beradasarkan grafik di atas, dapat dilihat bahwa titik-titik yang ada menyebar secara acak baik di atas maupun di bawah sumbu Y dan tidak membentuk pola tertentu. Sehingga dapat disimpulkan bahwa model penelitian ini bebas dari gejala heteroskedastisitas.

Tabel 5

Hasil Uji Regresi

\begin{tabular}{|c|c|c|c|c|c|c|c|c|}
\hline \multirow{2}{*}{\multicolumn{2}{|c|}{ Model }} & \multicolumn{2}{|c|}{ Unstandardized Coefficients } & \multirow{2}{*}{$\begin{array}{c}\text { Standardized Coefficients } \\
\text { Beta }\end{array}$} & \multirow[b]{2}{*}{$\mathrm{t}$} & \multirow{2}{*}{ Sig. } & \multicolumn{2}{|c|}{ Collinearity Statistics } \\
\hline & & B & Std. Error & & & & Tolerance & VIF \\
\hline \multirow{5}{*}{1} & (Constant) & .569 & 2.575 & & .221 & .826 & & \\
\hline & $\mathrm{X} 1$ & 332 & .029 & .817 & 11.440 & .000 & .554 & 1.806 \\
\hline & Jenis Kelamin & .117 & .432 & .016 & .270 & .787 & .835 & 1.197 \\
\hline & Tahun Angkatan & -.573 & .194 & -.177 & -2.958 & .004 & .788 & 1.270 \\
\hline & Jumlah Pendapatan Perbulan & -.321 & .192 & -.102 & -1.670 & .098 & .753 & 1.328 \\
\hline
\end{tabular}

Sumber: data olahan

Berdasarkan hasil uji regresi, maka dapat diperoleh persamaan regresi sebagai berikut :

$\mathrm{KI}=\alpha+\mathrm{b}_{1} \mathrm{LK}+\mathrm{b}_{2} \mathrm{JK}+\mathrm{b}_{3} \mathrm{TA}+\mathrm{b}_{4} \mathrm{P} \mathrm{KI}=0,569+0,332 \mathrm{LK}+0,117 \mathrm{JK}-0,573 \mathrm{TA}-0,321 \mathrm{P}$

Berdasarkan persamaan regresi di atas maka dapat dianalisis sebagai berikut :

1. Nilai konstanta sebesar 0,569 dengan nilai positif. Hal itu menunjukkan bahwa keputusan investasi (KI) bernilai 0,569 jika variabel literasi keuangan (LK), jenis kelamin (JK), tahun angkatan (TA) dan pendapatan (P) bernilai 0.

2. Variabel literasi keuangan (LK) memiliki korfisien regresi sebesar 0,332 dengan nilai positif. Hal ini menujukkan arah dari pengaruh literasi keuangan terhadap keputusan investasi adalah signifikan positif. Jadi setiap kenaikan $1 \%$ variabel literasi keuangan, maka akan menyebabkan menaiknya pengambilan keputusan investasi sebesar 0,332 dengan asumsi variabel yang lain bernilai konstan. Hal ini juga dapat berarti bahwa semakin tinggi literasi keuangan seseorang maka semakin baik pengambilan keputusan investasinya dan sebaliknya.

3. Variabel jenis kelamin (JK) memiliki koefisien regresi yang positif yaitu sebesar 0,117 . Hal ini menunjukkan arah pengaruh antara jenis kelamin terhadap keputusan investasi yaitu signifikan positif. Namun, nilai signifikansi variabel JK sebesar 0,787 dan lebih besar dari 0,05. Ini menunjukkan bahwa variabel JK tidak berpengaruh signifikan terhadap keputusan investasi mahasiswa.

4. Variabel tahun angkatan (TA) memiliki koefisien regresi yang negatif yaitu $-0,573$. Hal ini menunjukkan arah pengaruh antara tahun angkatan terhadap keputusan investasi yaitu signifikan negatif. Jadi setiap kenaikan $1 \%$ variabel tahun angkatan maka menyebabkan menurunnya pengambilan keputusan investasi sebesar 0,395 dengan asumsi variabel yang lain bernilai konstan.

5. Variabel pendapatan $(\mathrm{P})$ memiliki koefisien regresi negatif yaitu $-0,321$. Hal ini menunjukkan arah pengaruh antara pendapatan terhadap keputusan investasi yaitu signifikan negatif. Jadi setiap kenaikan $1 \%$ variabel pendapatan maka menyebabkan menurunnya pengambilan keputusan investasi sebesar 0,321 dengan asumsi variabel yang lain bernilai konstan. Selain itu, nilai signifikansi variabel $\mathrm{P}$ sebesar 0,098 dan lebih besar dari 0,05. Ini menunjukkan bahwa variabel $P$ tidak berpengaruh signifikan terhadap keputusan investasi mahasiswa.

Tabel 2.

Hasil Uji Determinasi

\begin{tabular}{|l|r|r|r|r|}
\hline Model & R & R Square & Adjusted R Square & \multicolumn{1}{|c|}{ Std. Error of the Estimate } \\
\hline 1 & $.855^{\mathrm{a}}$ & .732 & .721 & 1.97450 \\
\hline
\end{tabular}

Sumber: data olahan

Nilai $R$ square diatas adalah sebesar 0,721 sehingga dapat diartikan bahwa 72,1\% keputusan investasi dapat dijelaskan oleh variabel literasi keuangan, jenis kelamin, tahun angkatan dan pendapatan. Sedangkan sisanya sebesar $26,8 \%$ dijelaskan oleh variabel lain yang tidak dimasukan dalam model penelitian.

Tabel 3.

Hasil Uji F

\begin{tabular}{|l|l|r|r|r|r|r|}
\hline \multicolumn{2}{|l|}{ Model } & Sum of Squares & df & Mean Square & F & Sig. \\
\hline \multirow{3}{*}{1} & Regression & 1010.667 & 4 & 252.667 & 64.809 & $.000^{\mathrm{b}}$ \\
\cline { 2 - 7 } & Residual & 370.373 & 95 & 3.899 & & \\
\cline { 2 - 8 } & Total & 1381.040 & 99 & & & \\
\hline
\end{tabular}

Sumber: data olahan 
Berdasarkan tabel diatas menunjukkan bahwa nilai signifikansi yang diperoleh adalah 0,000 . Hal ini menunjukkan bahwa nilai signifikansi $<0,05$ maka literasi keuangan, jenis kelamin, tahun angkatan dan pendapatan secara simultan berpengaruh dalam pengambilan keputusan investasi.

Berdasarkan hasil uji t pada Tabel 5 diatas, maka dapat dijelaskan sebagai berikut :

1. Pengaruh literasi keuangan terhadap keputusan investasi, variabel literasi keuangan memiliki nilai signifikansi sebesar 0,000 yang berarti lebih kecil dari 0,05 sehingga $\mathrm{H}_{1}$ diterima. Maka dapat disimpulkan bahwa literasi keuangan berpengaruh positif signifikan terhadap keputusan investasi.

2. Pengaruh jenis kelamin terhadap keputusan investasi, variabel jenis kelamin memiliki nilai signifikansi sebesar 0,787 yang berarti lebih besar dari 0,05 sehingga $\mathrm{H}_{2}$ ditolak. Maka dapat disimpulkan bahwa gender atau jenis kelamin tidak berpengaruh positif signifikan terhadap keputusan investasi.

3. Pengaruh tahun angkatan terhadap keputusan investasi, variabel tahun angkatan memiliki nilai signifikansi sebesar 0,004 yang berarti lebih kecil dari 0,05 sehingga $\mathrm{H}_{3}$ diterima. Maka dapat disimpulkan bahwa tahun angkatan berpengaruh positif signifikan terhadap keputusan investasi.

4. Pengaruh pendapatan terhadap keputusan investasi, variabel pendapatan memiliki nilai signifikansi sebesar 0,098. Itu artinya lebih kecil dari 0,05 , sehingga $\mathrm{H}_{4}$ ditolak. Maka dapat disimpulkan bahwa pendapatan tidak berpengaruh positif signifikan terhadap keputusan investasi.

\section{Pembahasan}

\section{Pengaruh Literasi Keuangan terhadap Keputusan Investasi}

Hasil pertingan regresi dalam penelitian ini diperoleh bahwa variabel literasi keuangan memiliki nilai signifikansi sebesar 0,000 dimana nilai ini lebih kecil dari batas toleransi kesalahan yaitu 0,05. Sehingga dapat disimpulkan bahwa $\mathrm{H}_{1}$ diterima. Hal ini berarti variabel literasi keuangan berpengaruh positif signifikan terhadap keputusan investasi. oleh karena itu, pengambilan keputusan investasi yang dilakukan oleh Mahasiswa FE UST tergantung literasi keuangan yang mereka pahami. Semakin tinggi tingkat literasi keuangan seseorang, maka semakin baik pula pengambilan keputusan investasi yang diambil. Penelitian ini tentunya sejalan dengan penelitian yang telah dilakukan oleh (Pritazahara \& Sriwidodo, 2015), (Merawati \& Putra, 2015), dan (Faidah, 2019). Literasi keuangan yang baik ditunjukkan dengan pemahan yang baik mengenai pengetahuan umum keuangan, asuransi, tabungan dan pinjaman serta investasi. Literasi keuangan sangat penting bagi seseorang agar mereka tidak salah dalam mengambil keputusan investasinya. Dengan begitu mereka akan lebih berhati-hati dalam memilih investasi yang tepat.

\section{Pengaruh Variabel Jenis Kelamin terhadap Keputusan Investasi}

Hasil perhitungan regresi dalam penelitian ini diperoleh bahwa variabel jenis kelamin memiliki nilai signifikansi sebesar 0,787 diimana nilai ini lebih besar dari batas toleransi kesalahan yaitu 0,05. Sehingga dapat disimpulkan bahwa $\mathrm{H}_{2}$ ditolak. Hal ini berarti variabel jenis kelamin tidak berpengaruh positif signifikan terhadap keputusan investasi. Selain itu, ini membuktikan bahwa pengambilan keputusan investasi yang dilakukan oleh Mahasiswa FE UST tidak dipengaruhi oleh jenis kelamin. Hasil penelitian ini sama dengan penelitian yang telah dilakukan oleh (Pertiwi, 2018) dan (W. W. Putri, 2019) bahwa jenis kelamin tidak mempengaruhi keputusan investasi seseorang. Ini menandakan pula bahwa mahasiswa FE UST baik laki-laki maupun perempuan sudah tidak asing lagi akan investasi. Pada saat ini, baik tidaknya keputusan investasi didasarkan pada masing-masing individu bukan pada jenis kelamin. Jadi, laki-laki maupun perempuan mempunyai kesempatan yang sama akan keputusan investasi.

\section{Pengaruh Variabel Tahun Angkatan terhadap Keputusan Investasi}

Hasil perhitungan regresi ditemukan bahwa variabel tahun angkatan memiliki nilai signifikansi sebesar 0,004 yang nilainya lebih kecil dari batas toleransi kesalahan yaitu 0,05 sehingga dapat disimpulkan bahwa $\mathrm{H}_{3}$ diterima. Itu tandanya bahwa tahun angkatan memiliki pengaruh yang signifikan terhadap keputusan investasi. Hal ini menunjukkan bahwa dalam pengambilan keputusan investasi, Mahasiswa FE UST dipengaruhi oleh tahun angkatan mereka. Dalam penelitian ini, responden yang digunakan adalah Mahasiwa FE UST tahun angkatan 2017 sampai 2020. Responden tahun angkatan 2017 lebih mendomonasi daripada tahun-tahun lainnya. Hasil ini menandakan bahwa mahasiswa dengan tahun masuk lebih awal akan memiliki tingkat pengambilan keputusan investasi yang lebih baik. Hasil perhitungan regresi ditemukan bahwa variabel tahun angkatan memiliki nilai signifikansi sebesar 0,004 yang nilainya lebih kecil dari batas toleransi kesalahan yaitu 0,05 sehingga dapat disimpulkan bahwa $\mathrm{H}_{3}$ diterima. Itu tandanya bahwa tahun angkatan memiliki pengaruh yang signifikan terhadap keputusan investasi. Hal ini menunjukkan bahwa dalam pengambilan keputusan investasi, Mahasiswa FE UST dipengaruhi oleh tahun angkatan mereka Dalam penelitian ini, responden yang digunakan adalah Mahasiwa FE UST tahun angkatan 2017 sampai 2020. Responden tahun angkatan 2017 lebih mendomonasi daripada tahun-tahun lainnya. Hasil ini menandakan bahwa mahasiswa dengan tahun masuk lebih awal akan memiliki tingkat pengambilan keputusan investasi yang lebih baik. 
Pengaruh Variabel Pendapatan terhadap Keputusan Investasi

Hasil dari perhitungan regresi dalam penelitian ini diperoleh bahwa variabel pendapatan memiliki nilai signifikansi sebesar 0,098, dimana nilai ini lebih besar dari batas toleransi kesalahan yaitu 0,05 sehingga dapat disimpulkan bahwa $\mathrm{H}_{4}$ ditolak. Hal ini menandakan bahwa jumlah pendapatan tidak memiliki pengaruh positif signifikan terhadap keputusan investasi Mahasiswa FE UST. Penelitian ini didukung oleh (R. Putri \& Rahyuda, 2017) dan (Pertiwi, 2018) yang menyatakan bahwa pendapatan tidak berpengaruh terhadap keputusan investasi seseorang. Banyak sedikitnya jumlah pendapatan mahasiswa tidak mempengaruhi keputusan investasi yang dilakukan oleh mahasiswa tersebut. Hal ini menandakan bahwa Mahasiswa FE UST tidak harus memiliki tingkat pendapatan yang tinggi dalam mengambil keputusan investasi.

\section{Simpulan}

Berdasarkan penelitian yang dilakukan, maka dapat disimpulkan sebagai berikut :

1. Literasi Keuangan berpengaruh secara signifikan teradap keputusan investasi Mahasiswa FE UST. Semakin baik tingkat literasi keuangannya maka semakin baik pula keputusan investasi yang diambil.

2. Faktor demografi pada penelitian kali ini yaitu jenis kelamin, tahun angkatan dan pendapatan. Dari ketiga faktor tersebut, hanya tahun angkatan yang berpengaruh terhadap keputusan investasi Mahasiswa FE UST. Faktor lainnya seperti jenis kelamin dan pendapatan pada penelitian kali ini tidak berpengaruh secara signifikan.

\section{Daftar Pustaka}

Aini, N., Syafitri, L., \& Wijaya, T. (2016). Pengaruh Literasi Keuangan dan Faktor Demografi Terhadap Keputusan Investasi di Pasar Modal (Stusi Kasus Karyawan PT. Semen Baturaja (PERSERO) Tbk). Jurnal Ilmu Manajemen, 1-12.

Aminatuzzahra. (2014). Persepsi Pengaruh Pengetahuan Keuangan, Sikap Keuangan, Sosial Demografi Terhadap Perilaku Keuangan dalam Pengambilan Keputusan Investasi Individu (Studi Kasus pada Mahasiswa Magister Manajemana Universitas Diponegoro). 23(2), 70-96. https://doi.org/10.14710/jbs.23.2.70-96

Chen, H., \& Volpe, R. P. (1998). An Analysis of Personal Financial Literacy Among College Students. 7(2), 107-128.

Faidah, F. (2019). Pengaruh Literasi Keuangan dan Faktor Demografi terhadap Minat Investasi Mahasiswa. 5(3), 251-263.

Kusumawarhani, R., Cahyawani, P. D., \& Ningrum, N. K. (2020). Analisis Perbedaan Tingkat Literasi Keuangan antara Mahasiswa Fakultas Ekonomi dan Mahasiswa Fakultas Non Ekonomi. Jurnal Ilmiah Manajemen, 10(9), 15-28.

Merawati, L. K., \& Putra, I. P. J. S. (2015). Kemampuan Pelatihan Pasar Modal Memoderasi Pengaruh Pengetahuan Investasi Dan Penghasilan Pada Minat Berinvestasi Mahasiswa. Jurnal Ilmiah Akuntansi Dan Bisnis, 10(2).

Pertiwi, M. M. (2018). Pengaruh Financial Literacy Dan Faktor Demografi Terhadap Keputsan Investasi Mahasiswa. Retrieved from http://library1.nida.ac.th/termpaper6/sd/2554/19755.pdf

Pritazahara, R., \& Sriwidodo, U. (2015). Pengaruh Pengetahuan Keuangan dan Pengalaman Keuangan terhadap Perilaku Perencanaan Investasi dengan Self Contol sebagai Variabel Moderating. 15(1), 28-37.

Putri, R., \& Rahyuda, H. (2017). Pengaruh Tingkat Financial Literacy dan Faktok Sosiodemografi terhadap Perilaku Keputusan Investasi Individu. 9, 3407-3434.

Putri, W. W. (2019). Pengaruh Literasi Keuangan, Efikasi Keuangan, dan Faktor Demografi terhadap Pengambilan Keputusan Investasi (Studi Kasus Mahasiswa Magister Manajemen Fakultas Ekonomi Universitas Andalas Padang). 4(1), 398-412.

Rasyid, R. (2012). Analisis Tingkat Literasi Keuangan Mahasiswa Program Studi Manajemen Fakultas Ekonomi Universitas Negeri Padang. 1(September), 91-106. 